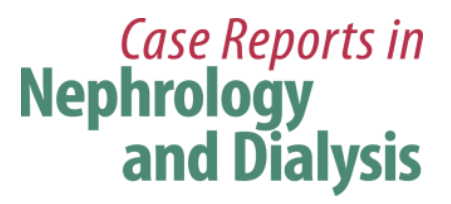

Case Rep Nephrol Dial 2017;7:49-54

DOI: $10.1159 / 000475838$

Publisned onIIne: IVlay 8,2017

(C) 2017 The Author(s)

Published by S. Karger AG, Basel

www.karger.com/cnd

This article is licensed under the Creative Commons Attribution-NonCommercial 4.0 International License (CC BY-NC) (http://www.karger.com/Services/OpenAccessLicense). Usage and distribution for commercial purposes requires written permission.

\title{
Cisplatin Therapy Does Not Worsen Renal Function in Severe Antenatal Bartter Syndrome
}

\author{
Thomas R. Welch ${ }^{a} \quad$ David R. Shaffer ${ }^{b} \quad$ Darren R. Feldman ${ }^{c}$ \\ a'Division of Nephrology, Upstate Medical University/Upstate Golisano Children's Hospital, \\ Syracuse, NY, USA; ${ }^{b} \mathrm{New}$ York Oncology and Hematology Albany Medical Center, \\ Albany, NY, USA; ${ }^{\circ}$ Genitourinary Oncology Service, Department of Medicine, Memorial \\ Sloan Kettering Cancer Center, New York, NY, USA
}

\section{Keywords}

Bartter syndrome $\cdot$ Testicular cancer $\cdot$ Chemotherapy $\cdot$ Cisplatin

\begin{abstract}
A 30-year-old man with severe antenatal Bartter syndrome, diagnosed and treated in infancy, developed testicular carcinoma. Despite the known renal complications of cisplatin, this drug was used for his chemotherapy because of its superior antineoplastic effect. Nonsteroidal anti-inflammatory drug administration was continued during cisplatin therapy. Despite an increase in his oral potassium requirement, renal function was maintained following completion of chemotherapy. In spite of its significant associated nephrotoxicity, cisplatin can be used in patients with severe antenatal Bartter syndrome if required for therapy of malignancy.




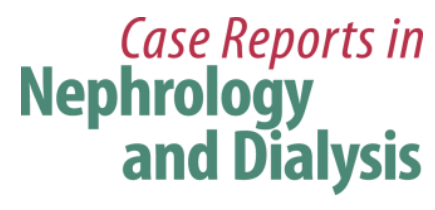

Case Rep Nephrol Dial 2017;7:49-54

DOI: $10.1159 / 000475838$

(C) 2017 The Author(s). Published by S. Karger AG, Base www.karger.com/cnd

Welch et al.: Cisplatin Therapy Does Not Worsen Renal Function in Severe Antenatal Bartter Syndrome

\section{Introduction}

Bartter syndrome was first described in 1962 [1] and for decades was considered an isolated tubulopathy associated with hypokalemia. By the 1980s, a much more severe clinical variant was described, including severe polyhydramnios, prematurity, life-threatening electrolyte disorder, failure to thrive, and hypercalciuric nephrocalcinosis [2]. This variant was initially called a number of things [2, 3] but ultimately became known as antenatal Bartter syndrome. Long-term therapy with nonsteroidal anti-inflammatory drugs (NSAIDs) became the mainstay of managing antenatal Bartter syndrome. Generous NSAID dosing and potassium supplementation, with or without a number of additional therapies, is still the cornerstone of therapy [4] and permits a normal quality of life in most patients. However, chronic kidney disease (CKD) may evolve in some, either related to progressive nephrocalcinosis or NSAID therapy.

Cisplatin is a potent disrupter of DNA synthesis which is a first-line chemotherapeutic agent for a number of solid tumors. In particular, cisplatin represents the essential component of curative chemotherapy regimens for patients with advanced testicular germ cell tumors. One of the major dose-limiting toxicities of cisplatin is renal dysfunction. Profound urinary electrolyte wasting may complicate administration, and CKD can develop after additional courses of therapy. We report the safe use of full-dose cisplatin in a young adult with severe antenatal Bartter syndrome and testicular cancer.

\section{Case Report}

The patient was a 30-year-old man who noted a left groin mass. A testicular tumor was identified upon exploration, and a left radical inguinal orchiectomy was performed. Pathology revealed a pT1 pure yolk sac tumor. Staging computed tomography scan demonstrated a 2.6-cm left para-aortic lymph node, and postorchiectomy markers were notable for an elevated $\alpha$-fetoprotein level of $135.9 \mathrm{ng} / \mathrm{dL}$. He was classified as having good-risk stage II-B nonseminoma and was recommended for systemic chemotherapy.

The patient had a long-standing history of renal disease and has been the subject (patient 6) of prior reports [5]. Briefly, he had been the 1,300-g product of a 32-week pregnancy complicated by severe polyhydramnios and preterm labor. He underwent a number of investigations for failure to thrive and at 19 months of age was admitted to the Clinical Research Center at Cincinnati Children's Hospital Medical Center.

During that admission, he was found to have hypokalemic alkalosis, polyuria, polydipsia, hyposthenuria, hypercalcemia, hypercalciuria, and nephrocalcinosis. Detailed metabolic studies demonstrated hyperprostaglandinuria and a decreased distal tubular chloride resorption. The diagnosis of antenatal Bartter syndrome was made, and he began therapy with high-dose indomethacin. He rapidly experienced improvement in his electrolyte disorder, polyuria, and growth.

For nearly 3 decades he did well, participating in interscholastic sports, graduating from college, and working in a professional career. He had very few medical problems, with the exception of an upper gastrointestinal hemorrhage related to indomethacin as a toddler. His medication regimen was occasionally adjusted in response to growth and laboratory testing 


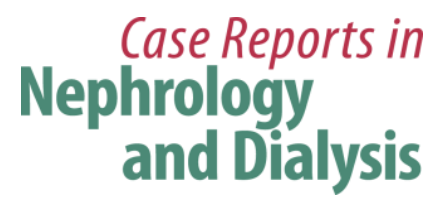

Case Rep Nephrol Dial 2017;7:49-54

DOI: $10.1159 / 00047583$

(c) 2017 The Author(s). Published by S. Karger AG, Basel www.karger.com/cnd

Welch et al.: Cisplatin Therapy Does Not Worsen Renal Function in Severe Antenata Bartter Syndrome

and at the time of cancer diagnosis consisted of tolmetin, potassium chloride, an H2 blocker, and chlorothiazide; the latter had been added to improve management of his hypercalciuria.

Since cisplatin was the preferred chemotherapy for his tumor, there was concern about dosing based upon his residual tubular dysfunction and established CKD (Table 1). In the absence of evidence-based guidelines and in an effort to insure optimal treatment of the tumor, it was decided to provide therapy at conventional doses with 4 cycles of etoposide $100 \mathrm{mg} / \mathrm{m}^{2}$ daily (175 mg) plus cisplatin $20 \mathrm{mg} / \mathrm{m}^{2}$ daily (35 mg) from days 1 to 5 of each 21-day cycle with Neulasta on day 6 or 7.

For each of the 4 cycles of chemotherapy, he was admitted for vigorous intravenous hydration with isotonic saline at $250 \mathrm{~mL} / \mathrm{h}$ over $4 \mathrm{~h}$ before cisplatin administration and isotonic saline at $250 \mathrm{~mL} / \mathrm{h}$ over $4 \mathrm{~h}$ after cisplatin administration. Cisplatin was administered in a dose of $35 \mathrm{mg}$ over $1 \mathrm{~h}$. Note that potassium supplementation was nearly always given orally, as per the patient's preference, with careful titration of the dose to daily lab results. The thiazide diuretic was held during chemotherapy. We did find that during days $1-5$, when he was receiving cisplatin, his oral potassium requirements were increased from a long-term maintenance dose of $80 \mathrm{mEq}$ per day to $160 \mathrm{mEq}$ per day on average. Interestingly, although his glomerular filtration rate remained relatively stable while on chemotherapy and has remained stable for up to 6 months after treatment, he has required increased oral potassium supplementation, compared to his baseline dose, for up to 6 months after completing chemotherapy, with a new required supplemental dose of potassium at $240 \mathrm{mEq}$ orally per day in 3 divided doses.

On day 9 of the first cycle of chemotherapy (e.g., 4 days after completing his last dose of cisplatin and etoposide), he developed severe diarrhea and was unable to consume adequate oral fluids to maintain hydration. He was dehydrated and in shock and was admitted for intravenous rehydration. His electrolytes at that time (Table 1) showed hypokalemia, profound hypophosphatemia, and relative acidosis. He was found to have Clostridium difficile colitis, which was treated with oral metronidazole and brief discontinuation of his NSAID. By the time of his second dose of cisplatin, his electrolytes had normalized. The subsequent courses of therapy were uneventful. His serum chemistries after the last dose of therapy and at follow-up 6 months later had returned to his baseline (Table 1). He achieved a clinical complete response with normalization of his $\alpha$-fetoprotein level and reduction in the size of the left para-aortic lymph node to $0.9 \mathrm{~cm}$ and was subsequently placed on active surveillance.

At the last follow-up, there was no evidence of tumor recurrence based on MRI imaging of the retroperitoneum and a normal $\alpha$-fetoprotein (Table 1). He did not develop significant ototoxicity, neurotoxicity, or atypical hematopoietic toxicity.

\section{Discussion}

At the time of this patient's initial diagnosis, antenatal Bartter syndrome was defined by physiological disturbances in renal electrolyte handling associated with evidence of hyperprostaglandinuria. The proximate defect was localized to the chloride-resorbing portion of the thick ascending limb of the loop of Henle. Such a defect was demonstrated in this patient by assessing chloride handling during hypotonic diuresis [5]. 


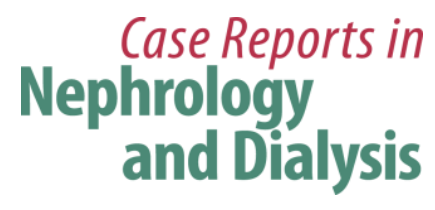

Case Rep Nephrol Dial 2017;7:49-54

DOI: $10.1159 / 00047583$

(C) 2017 The Author(s). Published by S. Karger AG, Base www.karger.com/cnd

Welch et al.: Cisplatin Therapy Does Not Worsen Renal Function in Severe Antenata Bartter Syndrome

More than a decade after this patient's diagnosis was made and treatment initiated, a series of elegant studies uncovered a number of tubular transporter mutations which were responsible for the Bartter phenotype. The severe antenatal phenotype is most often associated with defective functioning of the luminal potassium channel (ROMK) [6] or the luminal chloride cotransporter (Na-K-2Cl) [7]. Other phenotypes are associated with mutations in one of the basolateral chloride channels (ClC-Ka or $\mathrm{ClC}-\mathrm{Kb}$ ) or their barttin subunit [8]. Although molecular testing is now available for these mutations, it was not done in this patient, as his phenotype was clearly defined and responded well to NSAID therapy.

The development of testicular cancer in this patient presented an unprecedented therapeutic challenge. The most appropriate chemotherapy regimen for his tumor required the use of cisplatin, which carries significant nephrotoxicity. While cisplatin is useful in the management of many malignancies, there is perhaps no other malignancy where its role is as essential as in advanced testicular germ cell tumor. Even in the setting of advanced disease, cisplatin-based combination chemotherapy can achieve cures in the majority of patients and cannot be substituted with alternative agents without significantly compromising cure rates $[9,10]$. There were no established guidelines or published reports to inform cisplatin dosing in such a situation.

The nephrotoxicity of cisplatin is complex, with a number of underlying cellular mechanisms [11]. The proximate injury is probably damage to mitochondrial DNA. Renal tubular epithelial cells have a high density of mitochondria and basolateral transporters which move the drug into cells. Necrosis and apoptosis of tubular cells result, with functional consequences including electrolyte wasting and a concentrating defect.

In addition to tubular dysfunction, which may be transient, acute kidney injury, which may evolve into permanent CKD, is also a feature of cisplatin nephrotoxicity. The mechanism of CKD is even more poorly understood than that of tubulopathy but may be consequent to inflammation [12].

Although guidelines for cisplatin dosing in patients with CKD are conflicting, we elected to employ it in this patient given that it represents the optimal drug for a testicular germ cell tumor. Although there are no published reports of its use in antenatal Bartter syndrome, we hypothesized that the tubulopathy might be attenuated because the disorder itself already accounted for maximal tubular dysfunction. This is analogous to the well-known lack of diuretic response to furosemide in such patients [13]. Given that the extent to which his elevated creatinine represented established CKD, as opposed to the hemodynamic effects of NSAID therapy, was not clear, we did not consider withholding cisplatin on this basis. Although concurrent use of NSAID therapy with cisplatin is generally avoided, the critical importance of NSAID treatment to the prevention of profound diuresis in patients with Bartter syndrome led us to continue his usual dose of tolmetin. Indeed, the continuation of high-dose NSAID might have attenuated any inflammatory response.

We recognize that this is a unique case, and these observations are anecdotal. Nonetheless, we believe that this patient's course, including the apparent cure of his tumor without significant change in kidney function, validates the approach. 
Statement of Ethics

As a deidentified case report which did not involve clinical investigation, this report did not require institutional review board review.

\section{Disclosure Statement}

The authors declare no conflicts relevant to the subject matter of this article.

\section{References}

1 Bartter FC, Pronove P, Gill JR, MacCardle RC: Hyperplasia of the juxtaglomerular complex with hyperaldosteronism and hypokalemic alkalosis. A new syndrome. Am J Med 1962;33:811-828. Seyberth HW, Rascher W, Schweer H, Kuhl PG, Mehls O, Scharer K: Congenital hypokalemia with hypercalciuria in preterm infants: a hyperprostaglandinuric tubular syndrome different from Bartter syndrome. J Pediatr 1985;107:694-701.

-3 Shoemaker L, Welch TR, Bergstrom W, Abrams SA, Yergey AL, Vieira N: Calcium kinetics in the hyperprostaglandin E syndrome. Pediatr Res 1993;33:92-96.

-4 Reinalter SC, Grone HJ, Konrad M, Seyberth HW, Klaus G: Evaluation of long-term treatment with indomethacin in hereditary hypokalemic salt-losing tubulopathies. J Pediatr 2001;139:398-406.

5 Restrepo de Rovetto C, Welch TR, Hug G, Clark KE, Bergstrom W: Hypercalciuria with Bartter syndrome: evidence for an abnormality of vitamin D metabolism. J Pediatr 1989;115:397-404.

-6 Simon DB, Karet FE, Rodriguez-Soriano J, Hamdan JH, DiPietro A, Trachtman H, et al: Genetic heterogeneity of Bartter's syndrome revealed by mutations in the K+ channel, ROMK. Nat Genet 1996;14:152.

7 Simon DB, Karet FE, Hamdan JM, DiPietro A, Sanjad SA, Lifton RP: Bartter's syndrome, hypokalaemic alkalosis with hypercalciuria, is caused by mutations in the Na-K-2CI cotransporter NKCC2. Nat Genet 1996;13:183-188.

$>8$ Estevez R, Boettger T, Stein V, Birkenhager R, Otto E, Hildebrandt F, Jentsch TJ: Barttin is a CI channel $\beta$ subunit crucial for renal CI reabsorption and inner ear K+ secretion (letter). Nature 2001 29;414:558561.

-9 Bajorin DE, Sarosdy MF, Pfister DG, Mazumdar M, Motzer RJ, Sher HI, Geller NL, Fair WR, Herr H, Sogani $P$, et al: Randomized trial of etoposide and cisplatin versus etoposide and carboplatin in patients with good-risk germ cell tumors: a multiinstitutional study. J Clin Oncol 1993;11:598-606.

10 Horwich A, Sleijfer DT, Fossa SD, Kaye SB, Oliver RT, Cullen MH, Mead GM, et al: Randomized trial of bleomycin, etoposide, and cisplatin compared with bleomycin, etoposide, and carboplatin in goodprognosis metastatic nonseminomatous germ cell cancer: a multiinstitutional Medical Research Council/European Organization for Research and Treatment of Cancer trial. J Clin Oncol 1997;15:18441852.

11 Miller RP, Tadagavadi RK, Ramesh G, Reeves WB: Mechanisms of cisplatin nephrotoxicity. Toxins 2010;2:2490-2518.

12 Ramesh G, Reeves WB: TNF- $\alpha$ mediates chemokine and cytokine expression and renal injury in cisplatin nephrotoxicity. J Clin Invest 2002;110:835-842.

13 Kockerling A, Reinalter SC, Seyberth HW: Impaired response to furosemide in hyperprostaglandin E syndrome: evidence for a tubular defect in the loop of Henle. J Pediatr 1996;129:519-528. 
Table 1. Course of serum chemistries of the patient

\begin{tabular}{|c|c|c|c|c|c|c|c|}
\hline & $\begin{array}{l}\text { Diagnosis } \\
\text { (April 21, } \\
2016)\end{array}$ & $\begin{array}{l}\text { Cycle 1, D1 } \\
\text { (April 27, } \\
2016)\end{array}$ & $\begin{array}{l}\text { Clostridium } \\
\text { difficile } \\
\text { (May 5, } \\
\text { 2016) }\end{array}$ & $\begin{array}{l}\text { Cycle 2, D1 } \\
\text { (May 16, } \\
\text { 2016) }\end{array}$ & $\begin{array}{l}\text { Cycle 3, D1 } \\
\text { (June 6, } \\
\text { 2016) }\end{array}$ & $\begin{array}{l}\text { Cycle 4, D1 } \\
\text { (June 27, } \\
2016 \text { ) }\end{array}$ & $\begin{array}{l}6 \text { months after } \\
\text { treatment } \\
\text { (November 28, } \\
\text { 2016) }\end{array}$ \\
\hline $\mathrm{Na}$ & 135 & 136 & 132 & 131 & 135 & 133 & 139 \\
\hline $\mathrm{K}$ & 3.1 & 3.1 & 3.1 & 3.8 & 3.7 & 3.1 & 3 \\
\hline $\mathrm{Cl}$ & 95 & 102 & 86 & 97 & 98 & 95 & 96 \\
\hline $\mathrm{CO}_{2}$ & 32 & 26 & 24 & 27 & 28 & 27 & 34 \\
\hline BUN & 33 & 16 & 33 & 37 & 17 & 22 & 29 \\
\hline Creatinine & 1.6 & 1.4 & 1.7 & 1.7 & 1.5 & 1.3 & 1.6 \\
\hline $\mathrm{Mg}$ & 2.5 & 2.3 & 2.4 & 1.6 & 1.8 & 1.6 & 2.4 \\
\hline Phosphate & & 1.7 & 1.1 & 3.7 & 3.7 & 3.8 & 3.3 \\
\hline $\mathrm{Ca}$ & 9.7 & 8.8 & 9.9 & 8.6 & 8.5 & 8.4 & 9.9 \\
\hline AFP & 135.9 & & & & & & 8.8 \\
\hline
\end{tabular}

BUN, blood urea nitrogen; AFP, $\alpha$-fetoprotein. 